\title{
Akulturasi Budaya Mahasiswa Dalam Pergaulan Sosial Di Kampus (Studi Pada Mahasiswa Program Studi Pendidikan Sejarah Universitas PGRI Madiun)
}

\author{
Yosef Antonius Thaumaet ${ }^{1}$ dan Soebijantoro $^{2}$ \\ ${ }^{1}$ Program Studi Pendidikan Sejarah, FKIP, Universitas PGRI Madiun \\ 2Program Studi Pendidikan Sejarah, FKIP, Universitas PGRI Madiun
}

\begin{abstract}
Abstrak
Penelitian ini bertujuan untuk mendeskripsikan tentang Akulturasi Budaya serta untuk menganalisis proses akulturasi budaya mahasiswa dalam pergaulan sosial dan kendala yang dihadapi mahasiswa dalam proses akulturasi budaya dalam pergaulan sosial di kampus Universitas PGRI Madiun. Penelitian ini menggunakan metode penelitian kualitatif dan jenis penelitian ini adalah penelitian studi kasus. Penelitian ini dilakukan berdasarkan prosedur-prosedur berikut yaitu 1) tahap membangun kerangka konseptual, 2) tahap merumuskan permasalah penelitian, 3) tahapan pemilihan subyek penelitian, 4) tahapan pengembangan instrumen penelitian, 5) tahapan pengumpulan data, 6) tahapan analisa data dan 7) tahapan menarik kesimpulan. Analisis data yang digunakan dalam penelitian ini menggunakan cara yaitu 1) reduksi data, 2) penyajian data dan 3) penarikan kesimpulan. Analisis data ini berfungsi sebagai teknik dalam membuat kesimpulan-kesimpulan yang tepat dan dapat dipertanggung jawabkan. Akulturasi budaya adalah proses bertemunya beberapa kebudayaan di kampus, menyebabkan mereka memiliki hubungan pertemanan yang baik. Permasalahan yang dihadapai mampu mereka selesaikan dengan cara yang bijak. Hal ini karena kedua belah pihak memiliki kesadaran yang besar dalam saling memahami perbedaan. Pada dasarnya mereka berasal dari latar belakang yang sama, Jadi bentuk akulturasi yang terjadi di Program Studi pendidikan Sejarah Universitas PGRI Madiun seperti pergaulan sosial dan bahasa. Namun mereka tetap mampu mempertahankan budaya mereka tanpa menghilangkan dan menggantikan dengan hal baru. Mereka tetap bangga dengan budaya yang dibawa dari daerah asal tempat tinggal.
\end{abstract}

Kata Kunci: Akulturasi, Budaya, Pergaulan, Sosial

\section{Pendahuluan}

Komunikasi antar budaya pun ada proses akulturasi, yaitu cara bermasyarakat diakibatkan oleh kumpulan-kumpulan kultur luar, sehinnga elemen-elemen kultur baru bisa di terima dan dikemas seperti budaya asli namun tidak mempengaruhi sirnanya budaya asli yang ada (Koentjaraningrat, 2009: 202). Sesuai dengan paparan di atas disimpulkan bahwa kultur dapat mempersatukan niat agar memgembangkan semangat. Melalui kultur, setiap individu dapat belajar banyak hal. Mulai dari bagaimana harus menggunakan bahasa, membangun relasi, dan harus berteman. Dengan banyaknya proses dalam keberagaman budaya tertentu, tidak menutup kemungkinan terjadinya proses adaptasi budaya. Adaptasi budaya merupakan sebuah proses individu dalam memadukan kebiasaan pribadinya dan adat istiadat agar sesuai dengan budaya tertentu. Culture shock merupakan hal yang selalu dan hampir pasti terjadi gonjangan kebudayaan atau gegar budaya dalam proses akulturasi (Rusdiyanta, 2013: 110). Culture shock sendiri merupakan gejala sosial yang dialami oleh seorang mahasiswa 
ketika melanjutkan studinya ke suatu daerah dan lingkungan budaya baru. Kampus merupakan salah satu tempat terjadinya culture shock, Apalagi mahasiswa kampus tersebut terdiri dari berbagai wilayah yang ada di Indonesia tentu menjadikan kampus tersebut rentan terhadap culture shock (Gegar Budaya).

Salah satu kampus yang cukup heterogen yang menjadi tempat berkumpulnya mahasiswa di seluruh Indonesia dan memiliki berbagai mahasiswa yang beragam budaya adalah Universitas PGRI Madiun. Mahasiswa Universitas PGRI Madiun tidak hanya diminati mahasiswa dari kota Madiun saja, tetapi juga ada mahasiswa yang berasal dari daerah di luar Madiun, seperti Nusa Tenggara Timur, Papua, Kalimantan, Bali, dan wilayah lainnya. Khususnya Mahasiswa Pendidikan Guru Sejarah Universitas PGRI Madiun berasal dari daerah yang berbeda. Mereka ada yang berasal dari Madiun, Papua, Kalimantan, Ambon, Nusa Tenggara Timur dan daerah lain.

Dengan masuknya budaya mahasiswa luar pulau Jawa ke Universitas PGRI Madiun, maka proses terjadinya perbedaan budaya akan dialami oleh mahasiswa. Proses bertemunya beberapa mulai dirasakan ketika perbedaan budaya membangun relasi baik melalui masyarakat maupun sosial. Selain itu mahasiswamahasiswa luar Jawa juga diharuskan agar dapat beradaptasi di lingkungan sekitarnya supaya cepat menyesuaikan diri, mahasiswa luar pulau Jawa tidak bisa melindungi diri di kawasan kampus saja namun untuk menjalankan kepentingan-kepentingan yang berkaitan dengan perkuliahan. Dengan hadirnya perkembangan yang semakin canggih seperti zaman sekarang, maka perlu berhati-hati dengan perkembangan kultur yang berkembang setiap zaman.

Akulturasi budaya yang terjadi di Program Studi Sejarah Universitas PGRI Madiun sangat kompleks. Istilah akulturasi memiliki beberapa arti dari berbagai para serjana antropologi yang mengatakan bahwa proses sosial yang timbul bila suatu kelompok manusia dengan suatu kebudayaan asing dengan sedemikian rupa, sehingga unsur-unsur dari suatu kebudayaan asing itu lambat luan diterima dan diolah menjadi kebudayaan sendiri tanpa menhilangkan kebudayaannya sendiri (Koentjaraningrat, 2009: 202).

Sedangkan menurut sebuah komite dari social science research council, akulturasi adalah fenomena yang timbul sebagai hasil, jika kelompok-kelompok manusia yang mempunyai kebudayaan yang berbed-beda bertemu dan mengadakan kontak secara langsung dan terus-menerus yang kemudian menibulkan perubahan dalam pola kebudayaan yang original dari suatu kelompok atau kedua-duanya (Harsojo, dalam Warsito, 2012: 152:153). Terjadinya proses akulturasi karena adanya pengakuan peradaban tidak paksaan, lalu 
sekedar keserupaan seperti kualitas aktual nan terserap kesimpulan kesamaan derajat serta tanda kebiasaan. Sungguh-sungguh menjalin hubungan sosial di kampus, mahasiswa mengalami kontak sosial dengan sesama mahasiswa yang memiliki budaya berbeda. Misalnyya ada mahasiswa yang berasal dari Nusa Tenggara Timur, setiap hari komunikasi dengan orang Madiun atau orang Ponorogo lainnya.

Tentu saja akan sangat berusaha untuk memahami budaya mereka. Mahasiswa yang berasal dari luar Jawa masih mampu mempertahankan kebudayaan masing-masing, walau setiap hari terjadi kontak budaya. Budaya mempengaruhi kekuatan karakter Mahasiswa tetap memiliki jati diri yang bagus. Mahasiswa tidak membentuk budaya sendiri, namun mereka bertahan tanpa terjadi konflik dalam kehidupan sehari-hari. Mereka menyadari bahwa perbedaan adalah sesuatu hal yang biasa dan harus dihargai, bukan untuk dipermasalahkan atau dijadikan sebagai alasan untuk bermusuhan satu sama lain.

Universitas PGRI Madiun menjadi sebuah kampus terkemuka dalam tingkat provinsi seJawa Timur dan menghasilkan lulusan yang cerdas, berdaya saing, dan memiliki kemampuan berusaha. Maka perlu adanya keberagaman kehidupan di dalam kampus dengan berbagai budaya yang berbeda pula tidak jarang terjadi berbagai konflik dan kesalahpahaman dalam kehidupannya sehari-hari. Sebagai cara aturan buat mengantisipasi perselisihanperselisihan yang akan terjadi pengaruh pertantangan adat yaitu bersama-sama memahami maupun dapat mengerti sopan santun serta krakter adat atau kebiasaan penduduk berbeda, agar bisa berkomunikasi antarbudaya serta melaksanakan ketika berkomunikasi bersama-sama makluk berbeda.

Pentingnya selama mendalami korespondensi antara kebiasaan yang menjadi-jadi berhubung akan reseptif pertalian kita melalui penduduk-penduduk mengenai keberagaman adat nan bertantangan, selain itu masyarakat Indonesia juga banyak bermacam-macam dengan berbagai etnis, religi, latar belakang lingkungan (pura atau kampung), latar belakang pengetahuan, selanjutnya serupa.

Berdasarkan paparan di atas, tujuan penelitian ini adalah untuk menjelaskan proses Akulturasi budaya mahasiswa dalam pergaulan sosial di kampus Universitas PGRI Madiun, serta menjelaskan bentuk akulturasi pergaulan sosial yang terjadi di mahasiswa Universitas PGRI Madiun.

\section{Tinjauan Pustaka}

\section{A. Akulturasi}

Akulturasi atau (acculturation) atau culture contact (biasanya dipakai oleh serjana antropologi Inggris), tinjauan mengenai akulturasi bertambah ternama melalui mencari ilmu tentang komunikasi 
kebudayaan. Sedangkan keinginan terhadap gejala komunikasi kebudayaan, sangat dilaksanakan bagi para praktis, namun biasanya berawal dari hasil tentang penelitian mengenai "memori culture" (Poerwanto, 2010: 102). Definisi akulturasi pertama kali dikemukakan Redfield, Linton dan Herskovits (Poerwanto, 2010: 104), Acculturation com prehends these phenomena which result when groups of individuals having different cultures come into continous frist-hand contact, with subsequent changes in the original cultural patterns of either or both groups.

$$
\text { Artinya akulturasi adalah }
$$

memahami fenomena-fenomena yang terjadi ketika kelompok-kelompok inidividu yang memiliki budaya yang berbeda menjadi kontak-kontak tangan yang terusmenerus, dengan perubahan selanjutnya dalam pola budaya asli dari salah satu atau dua kelompok tersebut. Menurut Foster (1965: 45), proses akulturasi biasanya dimulai dari golongan atas dalam masyarakat yang tingal di kota.

Kenyataannya, pada masyarakat kota kebudayaan tradisional akan cepat hilang, kesatuan keluarga besar akan retak dan tumbuh nilai-nila budaya individualistis (Eko Handoyo, dkk, 2015: 88). Menurut pendapat Oberg (1960), akulturasi ialah satu proses bagaimana kita mengangkat budaya baru dengan mengangkat nilainilainya, perilaku, dan kemampuannya. Akulturasi merupakan satu sebutan yang dipakai untuk melukiskan sesuatu yang terjadi ketika orang yang bermula dari satu budaya masuk ke satu budaya yang berlainan. Akulturasi selalu ditandai dengan perubahan secara fisik dan psikologi yang terjadi sebagai hasil dari adaptasi yang dipersyaratkan untuk memfungsikan dalam konteks budaya yang baru atau budaya yang berbeda (1965:45). Namun menurut Foster akulturasi umumnya berangkat dari lapisan tempat ketika masyarakat yang tinggal di pura.

Dari beberapa pengertian ditarik kesimpulkan bahwa proses akulturasi adalah fenomena-fenomena yang terjadi dalam kelmpok manusia yang memiliki kebudayaan berlainan dan masuk melakukan komunikasi secara langsung yang terus menerus, akan mengakibatkan pergantian dalam cara berbudaya.

\section{B. Pergaulan Sosial}

Menurut Jacobus Ranjabar (2014: 70) sosial artinya Masyarakat. Masyarakat ialah totalitas melalui segala hubunganhubungan dalam hidup lingkugan dan bermasyarakat. Selanjutnya, menurut Poerwodarminto masyarakat adalah pergaulan hidup manusia bersama di suatu lingkungan dengan perkumpulan antara aturan tertentu. Dengan demikian pengertian masyarakat menurut Heskovismenulis, mengatakan bahwa masyarakat adalah kelompok individu yang diorganisasikan mengikuti cara hidup 
tertentu, sedangkan menurut J.L. Gilin J.P.Gilin mengatakan bahwa masyarakat itu adalah kelompok manusia yang terbesar mempunyai kebiasaan, tradisi, sikap dan perasaan persatuan yang sama.

Berdasarkan arti di atas, dapat ditarik definisi bahwa Masyarakat adalah kelompok manusia yang telah lama bertempat tinggal disuatu daerah yang tertentu dan mempunyai aturan (undangundang) yang mengatur tata hidup mereka, untuk menuju kepada tujuan yang sama. Selanjutnya, pergaulan bermula dari kata dasar "gaul" yang yaitu "hidup berteman (bersahabat)". Pergaulan diartikan 1) masalah bergaul, dan 2) hidup sosial (Aristoteles, 1999: 106).

Masalah dalam berbaur membuat seseorang berbaur dengan orang lain bemi memenuhi kepentingan kehidupanya sebagai makhluk yang bermasyarakar. Jadi makhluk sosial manusia perlu berbaur dengan sesama. Dengan begitu untuk mencukupi kepentingan dalam berbaur tersebut sehingga orang mau berhubungan satu dengan lainnya. Pergaulan memiliki akibat cukup besar dalam pembentukan sifat seorang individu.

Pergaulan yang dijalani itu akan menggambarkan sifat seseorang, baik pergaulan yang absolut ataupun pergaulan yang destruktif. Hal Serupa diungkapkan oleh Aristoteles bahwa manusia sebagai makhluk yang bermasyarakat (zoonpoliticon), yaitu manusia sebagai mahluk yang bermasyarakat dan tidak terpisahkan dari solidaritas dengan sesamanya. Pergaulan yang absolut dapat berwujud melalui kolaborasi membawa pribadi serta grup demi melaksanakan hal-hal yang absolut. meskipun pergaulan destruktif itu sangat terarah ke pergaulan liberal yang perlu ditinggalkan. Bisa dirumuskan bahwa pergaulan merupakan satu cara korelasi dengan maksud membentuk kedudukan yang soslidaritas, familiar dan perteman.

Lebih lanjut, pergaulan sosial adalah proses interaksi yang membentuk suatu relasi antara individu dengan individu lain melalui berinteraksi dengan tujuan membangun status kebersamaan, kekeluargaan dan perteman. Dalam dunia pergaulan juga terdapat beberapa faktor yang mempengaruhi, yaitu faktor umur, pekerjaan, keterikatan, lingkungan dan sebagainya. Pergaulan dan kehidupan sosial juga merupakan hal yang tidak bisa terlepas dari kehidupan masyarakat.

Sedangkan manusia merupakan makhluk sosial yang selalu bergaul dan membutuhkan sesamanya untuk melakukan interaksi sosial. Pergaulan dan kehidupan sosial ini memunculkan cara dan gaya tersendiri bagi setiap orang untuk bersosialisasi seluas mungkin.

\section{Kebudayaan}

Dalam era abad ke-19, sebutan kebudayaan biasanya dimanfaatkan buat wujud, literatur, pemikiran, angkasa, dan 
irma yang menunjukan menjadi peraturan ini semuanya disampaikan guna berkembangnya pemahaman maka ketrampilan dan keahlian ketrampilan di bentuk karena kalangan masyarakat (Peter Burke, 2001: 176-177). Kebudayaan adalah bentuk persepsi yang definisinya amat beraneka ragam. Kata kebudayaan berawal dari kata sanskerta buddhayah, yakni aliran dari buddhi yang berarti budi atau akal (Heri Poerwanto, 2000: 51).

Kebudayaan dapat diartikan hal-hal yang bersangkutan dengan akal. Bakker (1984: 37) menjelaskan kebudayaan sebagai kreasi serta kelanjutan nilai melingkupi seluruh apa yang ada dalam alam fisik, kelompok maupun masyarakat, yang komplet buat pengalaman tenaga manusia dan masyarakat. Sedangkan Herkovits, kebudayaan adalah bagian dari lingkungan yang diciptakan oleh manusia (Elly . M. Setiadi, 2007: 28).

Berdasarkan pendapat di atas dapat disimpulkan bahwa kebudayaan adalah sesuatu yang bakal merajai peringkat pendidikan, dan melingkupi teknik pendapat atau pandangan akan ada perasaan manusia, kemudian ketika dalam hidup sehari-hari, kebudayaan itu bersifat konseptual. Meskipun pelaksanaan kebudayaan merupakan sesuatu yang dijadikan karena manusia bagaikan makhluk berakal budi, berbentuk karakter, dan objek yang bersifat kelihatan, misalnya bahasa, sistem pengetahuan, institusi masyarakat, peralatan hidup. Beberapa

melancarkan aktifitas sosial.

Menurut Kluckhon para sarjana mengkaji unsur kebudayaan, kemudian menyimpulkan terdapat 7 (tujuh) unsur kebudayaan yang di anggap menjadi cultural Universal (dalam Soerjono Soekanto, 2001: 213). Berikut tujuh unsur kebudayaan, yaitu teknologi dan peralatan, sistem mata pencaharian, organisasi kemasyarakatan, bahasa, kesenian, sistem pengetahuan, serta sistem religi.

\section{Metode Penelitian}

Penelitian ini menggunakan pendekatan kualitatif dengan jenis studi kasus. Hubungan peneliti dengan subyek penelitian bersifat netral karena peneliti tidak memihak pada salah satu subyek. Subyek penelitian ini adalah seluruh mahasiswa Program Studi Pendidikan Sejarah, meliputi mahasiswa, dosen, dan karyawan.

Berdasarkan observasi awal, diperoleh data bahwa 50\% dari jumlah mahasiswa Prodi Pendidikan Sejarah memiliki jumlah 84 mahasiswa lebih dari orang pada tahun 2017. Berdasarkan jumlah tersebut, peneliti perlu mengambil sampel untuk diteliti secara sesuai dengan kebutuhan dan snowball. Lokasi penelitian adalah kampus Program Studi Pendidikan Sejarah Universitas PGRI Madiun dan sekitar Madiun serta kos yang menjadi 
tempat tinggal mahasiswa. Sumber data primer yang digunakan adalah seluruh mahasiswa Program Studi Pendidikan Sejarah. Untuk menguatkan data maka digunakan informan tambahan yaitu dosen, dan masyarakat sekitar kampus.

Hal ini digunakan agar data lebih banyak dan mendalam, sehingga hasilnya juga valid. Sumber data sekunder meliputi buku-buku atau referensi yang relevan dengan tema penelitian. Pengumpulan data dilakukan secara mendalam oleh peneliti agar data yang diperoleh lebih valid dan relevan dengan fokus penelitian. Pengumpulan data dilakukan melalui wawancara dan observasi. Observasi dilakukan untuk melihat peristiwa di kampus, misalnya bagaimana mahasiswa bergaul dengan teman yang berasal dari Jawa maupun luar Jawa di kampus, sementara mereka berasal dari daerah yang berbeda.

Selain itu, akan melihat bagaimana cara mereka melakukan akulturasi budaya satu sama lain. Metode penelitian kulitatif Berg (dalam Djam'an satori dan Aan 2017:22-23). yakni Penelitian kualitatif merupakan: penelitian yang fokus pada hal yang terutama pada sifat suatu benda atau pelayanan, melalui peristiwa atau fenomenal yaitu akibat masyarakat dibelakang peristiwa itu digunakan sebagai pengetahuan bermanfaat untuk satu pertimbangan ide berupa sumbanganya tentang ide, rasional, kearifan, persoalanpersoalan dalam masyarakat serta aktivitas. Jenis penelitian yang digunakan adalah jenis penelitian studi kasus. Studi kasus (case study) adalah cara untuk mengumpulkan serta mengkaji data berkanaan dengan satu kasus. Sesuatu dijadikan kasus umumny karena ada konflik, kesusahan, gangguan, digresi, namun bisa juga sesuatu dijadikan kasus walaupun tidak ada persoalan, apalagi menjabat kasus karena kelebihan atau kesuksesan. (Nana Syaodih, 2012: 77-78).

\section{Hasil Dan Pembahasan}

\section{A. Proses Akulturasi Budaya Mahasiswa Dalam Pergaulan Sosial Di Kampus}

Pada lapisan masyarakat manapun akan selalu ada proses sosial yang terjadi, baik proses asosiatif maupun disosiatif. Salah satu proses yang terjadi adalah akulturasi budaya. Hal tersebut dapat terjadi di lingkungan masyarakat kompleks maupun di kampus akibat adanya interaksi dan kontak sosial dengan manusia lain. Akulturasi terjadi karena keragaman dalam masyarakat.

Menurut Suyono dalam Rumondor (1995: 208), akulturasi merupakan pengambilan atau penerimaan satu atau beberapa unsur kebudayaan yang berasal dari pertemuan dua atau beberapa unsur kebudayaan yang saling berhubungan atau saling bertemu. Salah satu fenomena yang terjadi adalah di kalangan mahasiswa 
Program Studi Pendidikan Sejarah. Dinamika di kampus sangat beragam. Mereka bergaul dengan teman kampus tanpa membedakan asal daerah, bahasa, agama dan ras, namun ternyata mahasiswa mampu bekerjasama walau memiliki banyak perbedaan dan kekurangan. Hal ini terlihat dari kekompakan untuk menyelesaikan tugas dari dosen ataupun kegiatan Program Studi.

Proses akulturasi budaya dapat dilihat di kalangan mahasiswa melalui beberapa kegiatan yang mereka lakukan dikampus, baik kegiatan kemahasiswaan maupun kegiatan dalam rangka menyelesaikan tugas perkuliahan. Kegiatan tersebut Pertama adalah Praktik Pengalaman Lapangan (PPL). Saat semester 7, dalam melaksanakan PPL, Mahasiswa Program Studi Pendidkan Sejarah ditempatkan di Sekolah menegah pertama (SMP) dan juga sekolah menengah atas (SMA) khususnya daerah Kota Madiun.

Dalam satu sekolah latihan, ada 2-3 mahasiswa yang berasal dari rombel yang berbeda. Mereka diacak agar saling dapat berbaur. Tentu saja sebelumnya mereka hanya sebatas saling kenal saja, tidak akrab sama sekali. Di SMP serta SMA mereka harus bekerja tim agar PPL dapat berjalan dengan baik. Tugas demi tugas mereka kerjakan agar mendapat hasil maksimal di sekolah latihan. Namun sebelumnya mahasiswa semester 7 terlebih dahulu membahas tentang segala keperluan PPL.
Mereka merancang teknis waktu observasi awal ke Sekolah, iuran untuk keperluan selama praktek dan diskusi mengenai teknik mengajar di SMP/SMA. Hal ini mereka lakukan untuk membangun kekompakan diantaranya karena kurang lebih 3 bulan mereka akan bersama dan berkegiatan di Sekolah.

Satu fenomena yang menarik terjadi di SMPN Jiwan Kabupaten Madiun saat mahasiswa PPL. Yaitu Ada 1 orang yang sering membolos, namun teman lain ikut menyemangati dan membantu dia agar dapat ujian PPL. Padahal awalnya mereka tidak 1 rombel. Mereka juga tidak berasal dari daerah yang sama. Asal daerah mereka adalah Nusa Tenggara Timur, Jawa, Kalimantan dan lain sebagainya. Perbedaan tersebut tentu saja membawa konsekuensi, diantaranya adalah perbedaan kebiasaan, budaya dan adat. Namun semua itu mampu mereka langgengkan masing-masing dalam pergaulan yang penuh dengan perbedaan.

Selain PPL, agenda kampus yang mengharuskan mereka kompak dan solid, misal ketika sedang pembelajaran di dalam kelas. Mereka harus mengerjakan setiap tugas dan soal yang diberikan bapak dan ibu dosen. Mahasiswa mampu beradaptasi dengan teman satu kelas di kampus. Mereka menjalin solidaritas tidak hanya di luar kampus, namun di dalam kelas juga. Walaupun perbedaan tetap menyelimuti mereka, misalnya dalam hal bahasa. Berikut 
ini merupakan cuplikan wawancara dengan mahasiswa asal Nusa Tenggara Timur:

“.... Ketika bergaul di kampus saya tetap mempertahankan bahasa saya, yaitu penggunaan bahasa NTT. Walaupun teman-teman ada yang dari Jawa....".

Hal tersebut menjelaskan bahwa mahasiswa tetap mampu membaur dalam perbedaan, namun unsur budaya yang mereka bawa tidak hilang. Keduanya masih dapat dipertahankan dengan baik, walau mengalami sedikit kendala dalam pelaksanaannya. Ternyata bahasa tidak menjadi kendala berat. Banyak mahasiswa dari luar Jawa mampu berprestasi. Terbukti terdapat mahasiswa yang lolos PKM didanai di tahun 2018 ini.Mereka dapat membuktikan bahwa walaupun berbeda namun tetap satu tujuan.

\section{B. Bentuk Akulturasi Pergaulan Sosial Pada Mahasiswa Program Studi Pendidikan Sejarah Universitas PGRI Madiun}

Manusia merupakan mahkluk sosial, artinya mereka tidak dapat hidup sendiri namun harus berdampingan dengan manusia lainnya. Karena manusia sewaktuwaktu akan membutuhkan bantuan dari orang lain dalam menjalankan kehidupan. Salah satu contohnya yaitu jika ingin mencapai suatu tujuan tertentu manusia akan saling bekerjasama untuk mencapai tujuannya tersebut. Kerjasama bisa dilakukan dengan orang lain yang ada pada lingkungan sekitar. Misalnya, orang yang ada di lingkungan kampus. Tentu kerjasama bisa terbentuk karena adanya kepentingan yang sama salah satunya kepentingan untuk mencapai suatu tujuan. Selain kerjasama, juga diperlukan kontak sosial.

Kontak sosial pada seluruh lapisan masyarakat, sebagian masyarakat atau antar individu dalam dua masyarakat memiliki pengaruh besar karena seseorang melakukannya setiap hari. Pada dasarnya manusia selalu hidup membutuhkan orang lain. Walau dalam keterpaksaan mereka melakukan hal tersebut. Kontak budaya antara kelompok yang menguasai dan dikuasai dalam seluruh unsur budaya, baik dalam kebiasaan, bahasa dan lain sebagainya. Biasanya masyarakat yang menguasai adalah masyarakat asli atau pribumi, karena jumlah mereka lebih banyak. Sedangkan kelompok yang dikuasai adalah kelompok pendatang yang jumlahnya lebih sedikit atau minoritas.

Dalam hal ini mahasiswa minoritas adalah mereka yang berasal dari NTT, Riau, Kalimantan, Papua dan daerah lainnya. Penilaian mahasiswa yang berasal dari luar Jawa kepada orang Jawa adalah baik. Alasan bahwa masyarakat Jawa merupakan masyarakat yang ramah juga diakui oleh mahasiswa. Berikut cuplikan keterangan mahasiswa asal NTT:

“... Orang Jawa itu baik-baik, ketika ada masalah, mereka sering membantu dalam banyak hal..." . 
Berdasarkan hal tersebut maka, dapat dijelaskan bahwa proses adaptasi budaya mahasiswa berjalan dengan baik. Mahasiswa berdiskusi antar angkatan. Walaupun terlihat ada mahasiswa dan mahasiswi yang mempunyai budaya yang tidak sama. Budaya adalah suatu cara hidup yang berkembang dan dimiliki bersama oleh kelompok sosial, kemudian diwariskan dari generasi ke generasi. Budaya terbentuk dari banyak unsur yang rumit, termasuk sistem agama dan politik, adat istiadat, bahasa, bangunan, dan karya seni.

Menurut Linton dan Herskovic menyataka akulturasi adalah Proses dua arah kebudayaan yang berbeda atau saling mempengaruhi dua kelompok yang saling mengadakan hubungan (dalam Poerwanto, 2010: 107). Interaksi sosial merupakan suatu tindakan atau hubungan timbal balik yang dilakukan oleh seseorang kepada orang lain. Dalam interaksi terdapat suatu stimulus bagi tindakan individu lain yang menjadi pasangannya.

Interaksi sosial dapat berjalan dengan baik ketika mereka memiliki persepsi yang sama dan sepaham. Pada dasarnya satu masyarakat dengan masyarakat lain memiliki budaya yang tidak sama, hal tersebut dipengaruhi oleh banyak faktor, diantaranya lingkungan alam. Misal budaya masyarakat pesisir cenderung kasar karena mereka tinggal sangat dekat dengan pantai sehingga ketika berbicara harus keras agar terdengar serta tidak kalah dengan ombak. Kendala yang Dihadapi Mahasiswa dalam Proses Akulturasi Budaya dalam Pergaulan Sosial di Kampus (Studi Kasus pada mahasiswa Program Studi Pendidikan Sejarah Universitas PGRI Madiun) adalah:

1. Asal daerah, adalah pengelompokan manusia berdasarkan asal daerah atau tempat tinggalnya, di desa atau kota.

Berdasarkan penggolongan ini dikenal dua kelompok masyarakat, yaitu masyarakat desa dan masyarakat kota. Masyarakat desa adalah kelompok orang yang tinggal di pedesaan atau berasal dari desa. Sedangkan masyarakat kota adalah kelompok orang yang tinggal di perkotaan atau berasal dari kota. Contoh diferensiasi asal daerah tampak dalam perilaku, tutur kata, cara berpakaian, cara menghias rumah, cara berinteraksi, dan lain-lain.

2. Bahasa, adalah kemampuan yang dimiliki manusia untuk berkomunikasi dengan manusia lainnya menggunakan tanda, misalnya kata dan gerakan. Bahasa juga dapat diartikan sebagai alat untuk menyampaikan sesuatu yang terlintas di dalam hati. Bahasa merupakan alat untuk beriteraksi atau alat untuk berkomunikasi untuk menyampaikan pikiran, gagasan, konsep atau perasaan. Kebiasaan, adalah pengulangan sesuatu secara terus-menerus atau dalam sebagian besar waktu dengan cara yang sama. Kebiasaan mengulangi melakukan 
sesuatu yang sama berkali-kali dalam rentang waktu yang lama dalam waktu berdekatan. Hal tersebut merupakan keadaan jiwa yang mendorongnya untuk melakukan perbuatan-perbuatanya tanpa berpikir dalam.

\section{Penutup}

\section{Kesimpulan}

Akulturasi budaya adalah proses bertemunya beberapa kebudayaan di kampus, menyebabkan mereka memiliki hubungan pertemanan yang baik. Permasalahan yang dihadapai mampu diselesaikan dengan cara bijak. Karena kedua belah pihak memiliki kesadaran yang besar dalam saling memahami perbedaan. Pada dasarnya mereka berasal dari latar belakang yang sama.

Bentuk akulturasi yang terjadi di Program Studi pendidikan Sejarah Universitas PGRI Madiun yaitu pergaulan sosial dan bahasa. Namun mereka mampu mempertahankan budayanya tanpa menghilangkan dan menggantikan yang baru. Mereka tetap bangga dengan budaya yang dibawa daerah asalnya. Bentuk akulturasi dalam pergaulan sosial yang terjadi, yaitu:

a. Perbedaan budaya membuat mahasiswa memiliki hubungan pertemanan yang baik.

b. Setiap permasalahan yang dihadapai mampu mereka selesaikan dengan cara yang baik. c. Walaupun ada perbedaan budaya namun mahasiswa memiliki kesadaran yang besar dalam saling memahami perbedaan.

Dengan demikian proses akulturasi yang terjadi di Program Studi Pendidikan Sejarah sangat beragam. Kenapa dikatakan beragam karena dengan adanya pertemuan beberapa budaya dapat menyebabkan mahasiswa memilki pertemanan yang baik. Terbukti dalam kegiatan yang diadakan oleh kampus Universitas PGRI Madiun, mahasiswa Program Studi Pendidikan Sejarah juga mengikuti event-event tersebut dan mereka mampu menjadi team yang akur dan kompak dalam kegiatan tersebut.

\section{Daftar Pustaka}

Handoyo Eko, Astute, Iswari, Alimi, Mustofa. 2015. Studi Masyarakat Indonesia, Yokyakarta: Ombak

Hartomo H. \& Aziz Arnicun. 1999. Ilmu Sosial Dasar. Jakarta: Bumi Aksara.

Koentjaraningrat. 2009. Pengantar Ilmu Antropologi. Jakarta: PT Rineka Cipta.

Komariah Aan \& Satori Djam`an. 2017. Metode Penelitian Kualitatif Bandung: Alfabeta.

Oriza Derman Vysca. 2016. Proses Adaptasi Dalam Mengahapi Komunikasi Antar Budaya Mahasiswa Rantau Di Universitas Telkom. Jurnal EProceeding Of Management (Vol.3).

Poerwanto Heri. 2010. Kebudayaan Dan Lingkungan. Yogyakarta: Pustaka Belajar.

Pratama Ahmad Shofa. 2017. Proses Akulturasi Dalam Komunitas (Studi Kasus Mahasiswa Non Sunda Di Komunitas Budaya Sunda Swanda). 
Jurnal E-Proceeding of Management (Vol.4).

Rahayu Rina \& Alimudin Arasy. 2015. Pengaruh Pendidikan, Lingkungan Keluarga, Dan Gaya Hidup Terhadap Perilaku Penyimpangan Kerja Dan Keuangan (Studi Empiris Pada Karyawan Devisi Finance \& Accounting PT Meratus Line). E-Jurnal Ilmu Manajemen Magistra (Vol 1).

Ranjabar Jacobus. 2013. Sistem Sosial Budaya. Bandung: Alfabeta.

Rusdiyanta Syarbaini Syahrial. 2013. DasarDasar Sosiologi. Yogyakarta: Graha Ilmu.

Setiadi M. Ely. Hakam Abdul Kama. Efendi Ridwan. 2007. Ilmu Sosial Dan Budaya Dasar. Jakarta: Kencana.

Subagyo Joko. 2004. Metode Penelitian Dalam Teori Dan Praktek. Jakarta: Rineka Cipta.

Sugiyono. 2017. Metode Penelitian Kombinasi (Mixed Methhods). Bandung: Alfabeta.

Sugiyono. 2017. Metode Penelitian \& Pengembangan Research And Development: Bandung: Alfabeta.

Sukmadinata Syaodih Nana. 2012. Metode Penelitian Pendidikan Bandung: PT Remaja Rosdakarya.

Tim UNIPMA. 2017. Pedoman Akademik IPS Universitas PGRI Madiun. Madiun: UNIPMA.

Utami Setyo Savitri Lusia. 2015. Teori-Teori Adaptasi Antar Budaya. Jurnal Komunikasi (Vol.7): 190.

Warsito. 2012. Antropologi Budaya. Yogyakarta: Penerbit Ombak. 